\title{
Economic analysis of irrigated melon cultivated in greenhouse with and without soil plastic mulching
}

\author{
Elvis M. de C. Lima ${ }^{1}$, Jacinto de A. Carvalho' ${ }^{1}$, Miguel A. Viol ${ }^{1}$, \\ Fátima C. Rezende ${ }^{1}$, Michael S. Thebaldi ${ }^{2} \&$ Adriano V. Diotto ${ }^{1}$ \\ ${ }^{1}$ Universidade Federal de Lavras/Departamento de Engenharia. Lavras, MG. E-mail: elviscastrolima@yahoo.com.br (Corresponding author); jacintoc@ufla.br; \\ gutoviol@hotmail.com; frezende@deg.ufla.br; adriano.diotto@deg.ufla.br \\ ${ }^{2}$ Centro Universitário de Formiga/Departamento de Engenharia Ambiental. Formiga, MG. E-mail: msthebaldi@uniformg.edu.br
}

\section{Key words:}

water depth

irrigation management

yield

\begin{abstract}
A B S T R A C T
The objective of this study was to analyze technically and economically the irrigated 'Gália' melon (Hybrid Nectar), cultivated in greenhouse with and without using plastic mulch covering on the soil. Simultaneously, two experiments were conducted using a completely randomized design (CRD), in which melon plants were submitted to five water availability levels, defined by $50,75,100,125$, and $150 \%$ of crop evapotranspiration, with four replicates. The difference between experiments were only about the soil covering with plastic mulch: with (CC) or without (SC) plastic mulch. The economically optimal irrigation depths were 208.83 and $186.88 \mathrm{~mm}$, resulting in yields of 50.85 and $44.51 \mathrm{t} \mathrm{ha}^{-1}$ for the experiments with and without mulching, respectively. The results showing the economically optimal irrigation depths were very close to those that produced the highest yield.
\end{abstract}

\section{Palavras-chave: \\ lâmina de irrigação manejo de irrigação produtividade}

\section{Análise econômica da irrigação do meloeiro Gália em ambiente protegido com e sem mulching}

\section{R E S U M O}

O objetivo do trabalho foi analisar, técnica e economicamente, a cultura do meloeiro rendilhado cultivado em ambiente protegido. Foram realizados simultaneamente dois experimentos utilizando-se delineamento inteiramente casualizado (DIC) cujas plantas do melão tipo Gália foram submetidas a cinco lâminas de irrigação definidas por 50, 75 , 100, 125 e 150\%, da evapotranspiração da cultura, com quatro repetições. Os experimentos se diferenciaram apenas pelo não uso (SC) ou uso (CC) de cobertura plástica do solo (mulching). As lâminas de água ótimas economicamente foram 208,83 e 186,88 mm, que resultaram nas produtividades de 50,85 e 44,51 tha-1 para os experimentos SC e CC, respectivamente. Os resultados permitiram concluir que as lâminas ótimas econômicas ficaram bastante próximas daquelas que produziram as maiores produções físicas, para ambos os experimentos. 


\section{INTRODUCTION}

Melon has high productive and commercial potential. In 2015, 223.746 thousand tons of melon were exported, representing an increment of $13.66 \%$ in relation to the year of 2014 (ABF, 2016). Noble melons have stood out in the national scene due to their productive and qualitative characteristics. To produce fruits with desirable characteristics, it is necessary to supply water in adequate quantity and moment.

Rational irrigation management presupposes careful use of the available water resource, to maximize the yield of the crops with efficient use of water, energy, fertilizers and other inputs employed in the production. Other goals can also be established, such as maximizing the net profit per water volume unit or per irrigated area unit (Frizzone, 2007).

Some studies have demonstrated that melon is sensitive to water deficit, showing a consequent reduction in production and size of the fruits under this condition (Dantas et al., 2011; Zeng et al., 2009; Cabello et al., 2009; Li et al., 2012). On the other hand, excessive water in the soil can cause, besides yield reduction, problems of fruit quality in different crops (Oliveira et al., 2011; Carvalho et al., 2011; Dogan et al., 2008).

Melon cultivation in protected environment, adequate irrigation management and the use of soil plastic cover are technologies widely spread; however, there is a lack of studies on the response of the melon crop under different conditions of irrigation conduction and management for the South of Minas Gerais.

Thus, this study aimed to analyze, technically and economically, the cultivation of 'Gália' melon in protected environment with different irrigation depths, with and without using plastic mulch on the soil.

\section{Material ANd Methods}

The experiment was carried out in a protected environment at the Federal University of Lavras, Lavras-MG, Brazil (21 ${ }^{\circ} 14^{\prime}$ $00^{\prime \prime}$ S; $45^{\circ} 00^{\prime} 00^{\prime \prime} \mathrm{W} ; 918 \mathrm{~m}$ ). The climate, according to Köppen's classification, is Cwa. The mean annual temperature is $20.4^{\circ} \mathrm{C}$ and the mean annual rainfall is $1460.0 \mathrm{~mm}$ (Dantas et al., 2007).

The study consisted of two experiments conducted simultaneously: experiment I used plastic covering or mulching (CC), while experiment II was conducted without covering on the soil (SC). Each experiment used a completely randomized design (CRD), in which 'Gália' melon plants (hybrid 'Néctar') were subjected to different water depths, defined by $50,75,100$, 125 and $150 \%$ of crop evapotranspiration, with four replicates, totaling 20 plots per experiment. The soil was covered with double-sided plastic (white/black). Sowing was performed on January 2, 2014, and transplantation on February 6, 2014, planting one seedling per pot.

The soil used to fill the pots was a dystroferric Red Latosol, with clayey texture, collected in the 0-0.20 m layer, which was air-dried and sieved through a $4-\mathrm{mm}$ mesh. After that, a sample was collected for fertility analysis, performed at the Laboratory of Soil Fertility of the Federal University of Lavras. The following analyses were performed: $\mathrm{pH}$ in water; $\mathrm{P}$ (phosphorus); K (potassium); Ca (calcium); Mg (magnesium);
$\mathrm{H}+\mathrm{Al}$ (hydrogen + aluminum); $\mathrm{Al}$ (aluminum); $\mathrm{SB}$ (sum of exchangeable bases); $\mathrm{CEC} \mathrm{(cation} \mathrm{exchange} \mathrm{capacity} \mathrm{at} \mathrm{pH} 7.0$ ); V\% (base saturation at CEC pH 7.0); OM (organic matter); $\mathrm{m}$ (aluminum saturation); micronutrients $\mathrm{Zn}$ (zinc), Fe (iron), Mn (manganese), $\mathrm{Cu}$ (copper), B (boron) and P-rem (remaining phosphorus). The methodology used in the analyses followed the laboratory worker manual of PROFERT-MG (2005).

A hole was made at the bottom of the pots (treatment of $100 \%)$, where a fitting and a pipe were attached, connecting the pot to a 2-L PET bottle to collect the drained water volume. Each pot received a layer of sand $(2 \mathrm{~kg})$, on which a fine polyethylene screen was placed. Then, the volume of the pots was completed with soil, sieved and fertilized according to the result of the fertility analysis and based on the recommendation of CFSEMG (1999). Each pot received $0.100 \mathrm{~kg}$ of dolomitic limestone, $2.5 \mathrm{~kg}$ of commercial organic compost, $0.036 \mathrm{~kg}$ of urea, $0.28 \mathrm{~kg}$ of single superphosphate and $0.0533 \mathrm{~kg}$ of potassium chloride.

The pots, with a useful volume of $20 \mathrm{~L}$, were placed on 0.20 - $\mathrm{m}$ high benches, at spacing of $1.0 \mathrm{~m}$ between benches and $0.50 \mathrm{~m}$ between pots. Plants were trained vertically on a single-stake system.

All lateral shoots were removed until the $11^{\text {th }}$ internode; in the subsequent nodes, two secondary stems per plant were left, to form one fruit per stem. In one leaf after the fruit, the secondary stem was cut and, after the production of flowers, artificial pollination was performed.

Drip irrigation was applied using pressure-compensating emitters, operating within the pressure range recommended by the manufacturer ( 5 to $40 \mathrm{kPa}$ ), with nominal flow rate of $4.0 \mathrm{~L} \mathrm{~h}^{-1}$, one dripper per plant. The coefficient of water distribution uniformity (CDU) of the irrigation system was determined (98.13\%), obtaining a mean flow rate of $4.02 \mathrm{~L} \mathrm{~h}^{-1}$.

Irrigations were daily performed and the water volume applied in each treatment was defined based on the amount of evapotranspired water in the treatment with $100 \%$ replacement. Before irrigation, the drained water volume was collected and measured. The water volume to be applied in the $100 \%$ replacement treatment was calculated based on the water balance equation: ET = I - D, in which ET is the evapotranspiration (consumed volume), I is the volume applied in the previous irrigation and $\mathrm{D}$ is the drained volume. In the $100 \%$ treatment, the applied volume corresponded to ET \pm $10 \%$; in the other treatments, the applied volume was calculated by multiplying the volume obtained for the $100 \%$ treatment by the percentages defined for each treatment.

In the first 12 days after transplanting (DAT), a water depth of $10 \mathrm{~mm}$ was applied for the establishment of the seedlings and, from 13 DAT on, the treatments were differentiated.

Harvest was performed on April 24, 2014 (76 DAT) and the fruits were measured and weighed individually. Yield was calculated considering a density of 20,000 plants ha ${ }^{-1}(1.0 \mathrm{x}$ $0.50 \mathrm{~m})$.

The obtained data were subjected to analysis of variance and, when significant (Tukey test at 0.05 probability level), regression analysis was applied using the program Sisvar version 5.3 (Ferreira, 2011). 
The production function was obtained using the regression analysis between the commercial production and the water depths, adjusted by a second-order polynomial model (Eq. 1).

$$
\mathrm{Y}=\mathrm{f}(\mathrm{L})=\mathrm{a}+\mathrm{bL}+\mathrm{cL}^{2}
$$

where:

Y - yield, $\mathrm{t} \mathrm{ha}^{-1}$;

L - total water depth applied, mm; and,

$\mathrm{a}, \mathrm{b}$ and $\mathrm{c}$ - equation parameters.

The adjusted function was used to determine the water depth $\left(\mathrm{L}_{\max }\right)$ that can maximize the production (Eq. 2).

$$
\mathrm{L}_{\max }=\frac{-\mathrm{b}}{2 \mathrm{c}}
$$

The profit of the production was obtained by the difference between the total monetary value of the production and the costs of water application and fixed cost of the production system, including the irrigation system (Eq. 3).

$$
\mathrm{R}(\mathrm{L})=\mathrm{P}_{\mathrm{y}} \cdot \mathrm{Y}-\mathrm{P}_{\mathrm{L}} \cdot \mathrm{L}-\mathrm{C}
$$

where:

$\mathrm{R}(\mathrm{L})$ - profit, $\mathrm{R} \$ \mathrm{ha}^{-1}$;

$\mathrm{P}_{\mathrm{y}} \quad$ - melon price, $\mathrm{R} \$ \mathrm{t}^{-1}$;

$\mathrm{Y}$ - melon yield, $\mathrm{t} \mathrm{ha}^{-1}$;

$\mathrm{P}_{\mathrm{L}} \quad$ - price of the factor water, $\mathrm{R} \$ \mathrm{~mm}^{-1}$;

$\mathrm{L}$ - total water depth applied, $\mathrm{mm}$; and,

C - cost of the constant factors maintained in the experiment, $\mathrm{R} \$$.

The price of the melon $\left(\mathrm{P}_{\mathrm{y}}\right)$, referring to the harvest period, was obtained at the CEASA/MG (2015) and showed mean value of $\mathrm{R} \$ 3500.00 \mathrm{t}^{-1}$ during this period.

The cost of water depth $\left(\mathrm{P}_{\mathrm{L}}\right)$, in $\mathrm{R} \$ \mathrm{~mm}^{-1}$, considered the costs of energy, labor, maintenance and repairs of a pumping system, fixing some parameters and conditions, such as: localized drip irrigation; area of 1 ha; 20,000 plants ha ${ }^{-1}$; water source close to the cultivation area; total manometric height of 60 m.w.c.; motor pump flow rate of $10.3 \mathrm{~m}^{3} \mathrm{~h}^{-1}$; motor pump set efficiency of $45 \%$ and irrigation system lifespan of 10 years. Under these conditions, the cost of the irrigation system was $\mathrm{R} \$ 5,876.00$, including all necessary constructions.

The cost of electricity for water pumping considered the investments, the irrigation system characteristics described above and a crop cycle of 75 days. The value of the kWh provided by the electric energy company (CEMIG) for March 2014 was $\mathrm{R} \$ 0.2527$. The price of the factor water $\left(\mathrm{P}_{\mathrm{L}}\right)$ was obtained by summing the costs of energy, labor, maintenance and repairs of the pumping system, which totaled $\mathrm{R} \$ 1.08 \mathrm{~mm}^{-1}$. The constant factors in the experiment had price of $\mathrm{R} \$ 23,511.84$.

Profit maximization was obtained by calculating the firstorder derivative of Eq. 1 with respect to $\mathrm{L}$ and equaling the derivative to the relation of prices of the factor water $\left(\mathrm{P}_{\mathrm{L}}\right)$ and of the product $\left(\mathrm{P}_{\mathrm{y}}\right)$, obtaining the equation of the optimal water depth $\left(\mathrm{L}_{\text {optimal }}\right)$ that maximized the profit (Eq. 4).

$$
\mathrm{L}_{\max }=\frac{\mathrm{P}_{\mathrm{L}}-\mathrm{P}_{\mathrm{Y}} \mathrm{b}}{2 \mathrm{P}_{\mathrm{Y}} \mathrm{c}}
$$

\section{Results AND Discussion}

The water depths applied in the experiment without soil cover were 92.66, 139.00, 169.36, 231.66 and $277.98 \mathrm{~mm}$ for the treatments of $0,75,100,125$ and $150 \%$, respectively. For the experiment with plastic cover on the soil, the applied water depths were 83.4, 125.20, 153.50, 208.66 and $250.28 \mathrm{~mm}$ for the treatments of 50,75, 100, 125 and $150 \%$, respectively. It was observed that the water depths obtained for the treatments of the SC experiment were superior to those for the treatments of the CC experiment. The results demonstrate that the soil cover induces the reduction in water consumption for irrigation, due to the reduction in evaporation.

Table 1 shows the summary of the analysis of variance for the SC experiment. It is observed that the treatments significantly affected the yield. Working with netted melon (cv. 'Bônus') cultivated in protected environment and irrigated based on water evaporated from the Class A pan, Araújo et al. (2010) observed that the yield was significantly influenced by the irrigation depths, increasing linearly with the increment in the irrigation depths.

The mean fruit yield showed quadratic polynomial variation, with the applied water depth (Figure 1). The mean yield in the treatments with plants subjected to water deficit (50 and 75\%) was lower than in treatments that received higher water depths (125 and 150\%).

The equation in Figure 1 was derived and equaled to zero (Eq. 5). Considering the hypothesis that $\mathrm{R}(\mathrm{L})$ has a maximum value (Eq. 3) and that water is the only variable factor, the

Table 1. Summary of the analysis of variance for the mean fruit yield $(\mathrm{Y})$ as a function of the irrigation treatments in the SC experiment

\begin{tabular}{ccc}
\hline SV & DF & MS Y $\left(\mathbf{t ~ h a}^{-1}\right)$ \\
Treatment & 4 & $322.28^{\star \star}$ \\
Residual & 15 & 59.18 \\
CV (\%) & & 18.90 \\
Mean & & 40.69 \\
\hline
\end{tabular}

**Significant by $\mathrm{F}$ test at 0.01 probability level

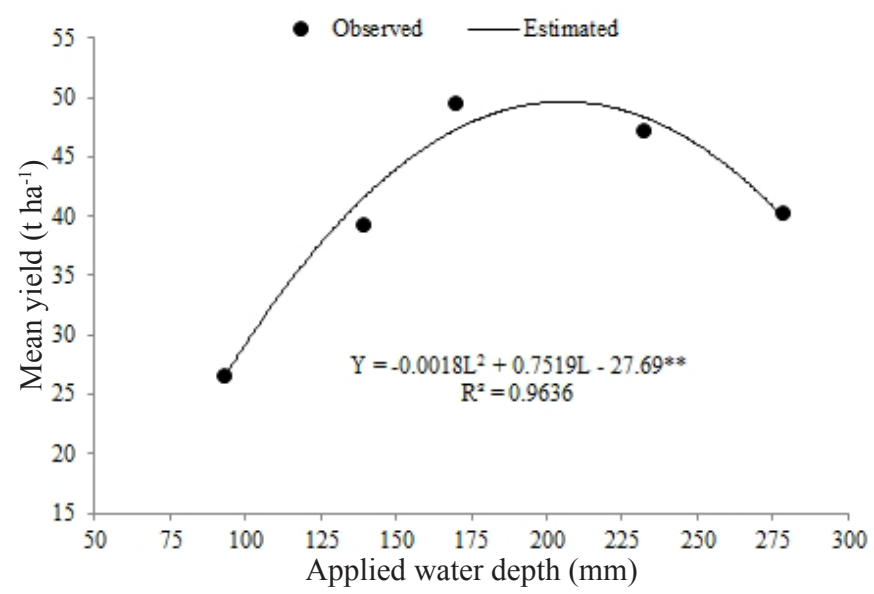

Figure 1. Mean yield of 'Gália' melon, cv. 'Néctar', as a function of different replacement depths, in the SC experiment 
maximum physical yield of $50.83 \mathrm{t} \mathrm{ha}^{-1}$ was obtained for an irrigation depth of $208.92 \mathrm{~mm}$.

$$
\frac{\partial \mathrm{Y}}{\partial \mathrm{L}}=-0.0036 \cdot \mathrm{L}+0.7519=0
$$

Li et al. (2012) and Zeng et al. (2009) obtained higher yields, 27.45 and $17.1 \mathrm{t} \mathrm{ha}^{-1}$, for the water depths of 178.6 and $210 \mathrm{~mm}$, respectively. The water depths applied by these authors were similar to those in the present study; however, the mean yields obtained were inferior. In two years of melon cultivation, 2005 and 2006, under field conditions, Dogan et al. (2008) obtained maximum values of mean yield, 41.7 and $34.4 \mathrm{t} \mathrm{ha}^{-1}$, for the applied water depths of 377 and $436 \mathrm{~mm}$, respectively. Similarly, Fabeiro et al. (2002) observed that the maximum yield, $51.25 \mathrm{t} \mathrm{ha}^{-1}$, can be obtained for the applied water depth of $407 \mathrm{~mm}$. The differences of water depths and yields observed between the studies with the melon crop may be due to the utilized cultivar, period and site in where the experiments were conducted.

The optimal irrigation depth $\left(\mathrm{L}_{\text {optimal }}\right)$ to obtain maximum economic efficiency was calculated by Eq. 6, which resulted in a value of $208.83 \mathrm{~mm}$, generating a yield of $50.85 \mathrm{t} \mathrm{ha}^{-1}$.

$$
\frac{\partial \mathrm{Y}}{\partial \mathrm{L}}=-0.0036 \cdot \mathrm{L}+0.7519=\frac{\mathrm{PL}}{\mathrm{PY}}
$$

The maximum physical yield of the factor water (Eq. 6), also known as marginal physical product $(\mathrm{MPPw})$ of the factor water, has an initially positive value and decreases as the total irrigation depth applied to the soil increases, as shown in Table 2. From the point at which the MPPw has null value, the antieconomic production stage is characterized, because the increment in the applied water depths leads to decrease of production (Carvalho et al., 2011).

Table 3 shows the summary of the analysis of variance for the mean yield of melon fruits as a function of the treatments obtained in the CC experiment.

It is observed that the treatments significantly interfered with the analyzed variable in the experiment with plastic cover on the soil. Monteiro et al. (2008) observed that using mulch induced an increment in melon yield of approximately

Table 2. Marginal physical product (MPPw) of the factor water for the without plastic mulch (SC) experiment

\begin{tabular}{cc}
\hline Irrigation depths $(\mathrm{mm})$ & MPPw \\
92.66 & 0.4185 \\
139.00 & 0.2517 \\
169.36 & 0.1424 \\
231.66 & -0.0819 \\
277.98 & -0.2486 \\
\hline
\end{tabular}

Table 3. Analysis of variance for the mean fruit yield (Y) as a function of the treatments, in the plastic mulch (CC) experiment

\begin{tabular}{lcc}
\hline SV & DF & MS Y $\left(\mathbf{t ~ h a}^{-1}\right)$ \\
Treatment & 4 & $140.61^{\star \star}$ \\
Residual & 15 & 22.81 \\
CV (\%) & & 12.42 \\
Mean & & 38.45 \\
\hline
\end{tabular}

${ }^{* *}$ Significant at 0.01 probability level
$10 \%$ in relation to the treatment without mulching. In the present study, there was no comparative analysis between the treatments; however, the yield was lower in the treatment with mulching.

Figure 2 shows the mean yield values $(\mathrm{Y})$ as a function of the irrigation depths obtained in each treatment (L). The regression analysis applied to the data indicates that the quadratic polynomial model described well the behavior for the considered interval, with determination coefficient $\left(\mathrm{R}^{2}\right)$ above $96 \%$.

The maximum physical yield for the experiment using soil cover was obtained by deriving the estimated production function (Figure 2) and equaling it to zero (Eq. 7).

$$
\frac{\partial \mathrm{Y}}{\partial \mathrm{L}}=-0.0026 \cdot \mathrm{L}+0.4857=0
$$

Maximum physical yield, $44.51 \mathrm{t} \mathrm{ha}^{-1}$, was obtained for an applied water depth of $186.88 \mathrm{~mm}$. Sharma et al. (2014) obtained mean yields between 54.2 and $78.7 \mathrm{tha}^{-1}$, for the mean irrigation depths of 383 and $550 \mathrm{~mm}$, respectively. The values were superior to those observed in the present study, probably due to crop management. Cabello et al. (2009) evaluated the effect of different irrigation levels on the yield of 'pele de sapo' melon, during the years of 2005 and 2006, and obtained the highest mean yields of the order of 41.5 (2005) and $37.2 \mathrm{t} \mathrm{ha}^{-1}$ (2006). The yield values were similar to those of the present study, but the applied water depths of 705 and $522.9 \mathrm{~mm}$, respectively, were superior, probably due to the cultivation environment and to the characteristic of the utilized cultivar.

The optimal irrigation depth $\left(\mathrm{L}_{\text {optimal }}\right)$ to obtain maximum economic efficiency was calculated by Eq. 8 , resulting in a value of $186.78 \mathrm{~mm}$, generating a yield of $44.51 \mathrm{t} \mathrm{ha}^{-1}$.

$$
\frac{\partial \mathrm{Y}}{\partial \mathrm{L}}=-0.0026 \cdot \mathrm{L}+0.4857=\frac{\mathrm{PL}}{\mathrm{PY}}
$$

To meet the different relationships between water price and melon price, a graph was constructed relating the economically optimal irrigation depth $\left(\mathrm{L}_{\text {optimal }}\right)$, as a function of the relationship of prices between the factor water and product $\left(\mathrm{P}_{\mathrm{L}} / \mathrm{P}_{\mathrm{y}}\right)$ for the SC and CC experiments (Figure 3 ).

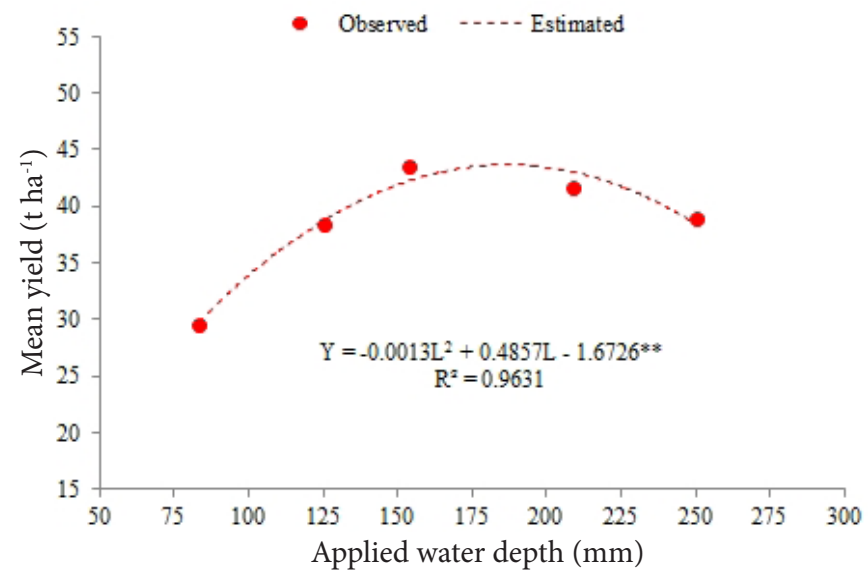

Figure 2. Mean yield of 'Gália' melon, cv. 'Néctar', as a function of different replacement depths, in the with plastic mulch (CC) experiment 


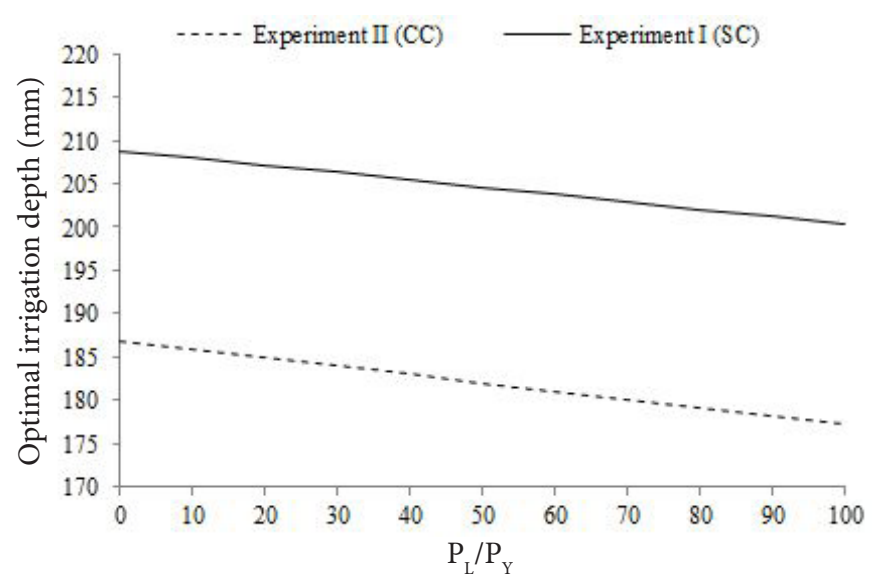

Figure 3. Economically optimal irrigation depth as a function of the relationship between the water price $\left(\mathrm{P}_{1}\right)$ and the product price (Py), for 'Gália' melon in the SC and CC experiments

There was a slight decrease in the economically optimal total irrigation depth always when the relationship between prices $\left(\mathrm{P}_{\mathrm{L}} / \mathrm{Py}\right)$ increased. Thus, considering as fixed the mean marketing price of melon, it is observed that, although the cost of water is incremented due, for example, to the increase in the energy tariff for pressurization of the irrigation system or to the charge on water use, the total irrigation depth to be applied is virtually the same.

\section{Conclusions}

1. Melon yield is significantly influenced by the adopted irrigation depths.

2. In the experiment without cover (SC), the highest physical yield (50.83 $\mathrm{tha}^{-1}$ ) was obtained with water depth of $208.92 \mathrm{~mm}$ and the highest economic profitability was obtained with water depth of $208.83 \mathrm{~mm}$; in the experiment with soil cover (CC), the water depth that led to highest physical yield $(186.88 \mathrm{~mm})$ was similar to the one that led to highest economic profitability $(186.78 \mathrm{~mm})$.

\section{ACKNOWLEDgments}

To the Minas Gerais Research Support Foundation (FAPEMIG) and to the National Council for Scientific and Technological Development (CNPq), for funding the project.

\section{Literature Cited}

ABF - Anuário Brasileiro da Fruticultura 2016. Santa Cruz do Sul: Editora Gazeta Santa Cruz, 2016. 88p.

Araújo, W. F.; Oliveira G. A.; Carvalho, F. K. de; Silva, W. M. da; Cruz, P. L. S.; Maciel, F. C. da S. Manejo da irrigação do meloeiro com base na evaporação do tanque classe A. Horticultura Brasileira, v.28, p.495-499, 2010. https://doi.org/10.1590/S010205362010000400020

Cabello, M. J.; Castellanos, M. T.; Romojaro, F.; Martínez-Madrid, C.; Ribas, F. Yield and quality of melon grown under different irrigation and nitrogen rates. Agricultural Water Management, v.96, p.866-874, 2009. https://doi.org/10.1016/j.agwat.2008.11.006
Carvalho, J. de A.; Rezende, F. C.; Aquino, R. F.; Freitas, W. A. de; Oliveira, E. C. Análise produtiva e econômica do pimentão-vermelho irrigado com diferentes lâminas, cultivado em ambiente protegido. Revista Brasileira de Engenharia Agrícola e Ambiental, v.15, p.569-574, 2011. https://doi.org/10.1590/S1415-43662011000600005

CEASA/MG - Centrais de Abastecimento do Estado de Minas Gerais. Disponível em: <http://www.minas.ceasa.mg.gov.br/detec/boletim/ boletimproduto/boletim_produto.php > Acessado em: 10 Fev. 2015.

CFSEMG - Comissão de Fertilidade do Solo do Estado de Minas Gerais. Café: Recomendação para o uso de corretivos e fertilizantes em Minas Gerais; 5. aproximação. Viçosa: CFSEMG, 1999. p.289-302.

Dantas, A. A. A.; Carvalho, L. G. de; Ferreira, E. Classificação e tendências climáticas em Lavras, MG. Ciência e Agrotecnologia, v.31, p.18621866, 2007. https://doi.org/10.1590/S1413-70542007000600039

Dantas, D. da C.; Medeiros, J. F. de; Freire, A. G. Produção e qualidade do meloeiro cultivado com filmes plásticos em repostas à lâmina de irrigação. Revista Ciência Agronômica, v.42, p.652-661, 2011. https://doi.org/10.1590/S1806-66902011000300011

Dogan, E.; Kirnak, H.; Berekatoglu, K.; Bilgel, L.; Surucu, A. Water stress imposed on muskmelon (Cucumis melo L.) with subsurface and surface drip irrigation systems under semi-arid climatic conditions. Irrigation Science, v.26, p.131-138, 2008. https://doi.org/10.1007/ s00271-007-0079-7

Fabeiro, C.; Olalla, M. F. de S.; Juan, J. A. de. Production of muskmelon (Cucumis melo L.) under controlled deficit irrigation in a semi-arid climate. Agricultural Water Management, v.54, p.93-105, 2002. https://doi.org/10.1016/S0378-3774(01)00151-2

Ferreira, D. F. Sisvar: Um sistema computacional de análise estatística. Ciência e Agrotecnologia, v.35, p.1039-1042, 2011. https://doi. org/10.1590/S1413-70542011000600001

Frizzone, J. A. Planejamento da irrigação com uso de técnicas de otimização. Revista Brasileira de Agricultura Irrigada, v.1, p.24-49, 2007. https://doi.org/10.7127/rbai.v1n100107

Li, Y.-J.; Yuan, B.-Z.; Bie, Z.-L.; Kang, Y. Effect of drip irrigation criteria on yield and quality of muskmelon grown in greenhouse conditions. Agricultural Water Management, v.109, p.30-35, 2012. https://doi. org/10.1016/j.agwat.2012.02.003

Monteiro, R. O. C.; Coelho, R. D.; Melo, P. C. T. de; Ferraz, P.; Chaves, S. W. P.; Shirahige, F. H.; Beltrame Neto, E.; Piedade, S. M. de S. Net melon performance as affeceted by the drip irrigation depth and mulching. Horticultura Brasileira, v.26, p.447-451, 2008. https:// doi.org/10.1590/S0102-05362008000400005

Oliveira, E. C.; Carvalho, J. de A.; Silva, W. G. da; Rezende, F. C.; Gomes, L. A. A.; Jesus, M. C. N. de. Análise produtiva e econômica do pepino japonês submetido a diferentes lâminas de irrigação. Revista Brasileira de Engenharia Agrícola e Ambiental, v.15, p.702-708, 2011. https://doi.org/10.1590/S1415-43662011000700008

PROFERT - MG. Manual do laboratorista. Programa interlaboratorial de controle de qualidade de análise de solo. Emissão dia 6 de julho de 2005.

Sharma, S. P.; Leskovar, D. I.; Crosby, K. M.; Volder, A.; Ibrahim, A. M. H. Root growth, yield, and fruit quality responses of reticulatus and inodorus melons (Cucumis melo L.) to deficit subsurface drip irrigation. Agricultural Water Management, v.136, p.75-85, 2014. https://doi.org/10.1016/j.agwat.2014.01.008

Zeng, C.-Z.; Bie, Z.-L.; Yuan, B.-Z. Determination of optimum irrigation water amount for drip-irrigated muskmelon (Cucumis melo L.) in plastic greenhouse. Agricultural Water Management. v.96, p.595602, 2009. https://doi.org/10.1016/j.agwat.2008.09.019 